\title{
Universities of the Third Age and Their Role in Education and Preventive Gerontology
}

\author{
By Dorota Rynkowska ${ }^{1}$
}

\begin{abstract}
Rapid ageing leads to huge transformations in many areas of life - politics, economy, culture, education, medicine and care services, which in turn shapes the future of all people. Active lifestyle, education and better quality of geriatric care will undoubtedly improve the health and well-being of seniors. The growing population of elderly people, caused, among other things, by the increase in average life expectancy, and current trends in reproduction, migration and mortality, necessitate the development of a new vision on the functioning of seniors and their social roles in the transforming social reality.

One platform for the activity and cooperation of older people involves universities of the third age. Universities of the Third Age is an international initiative promoting lifelong learning. They are educational institutions for adults whose programme offers are targeted at seniors. Universities of the third age were established in response to rapid socio-demographic changes in society. They are part of the lifelong learning concept, where education in modern gerontology is regarded as a process enabling seniors to develop comprehensively, manage their own lives, be active in late adulthood, and develop and broaden their interests. The purpose of this article is to explain the idea behind universities of the third age as an unquestioned need to support seniors in education and adaptation to old age.
\end{abstract}

Key words: senior, ageing, education, gerontology, university

\section{Introduction}

Demographic processes that are currently observed in Europe, as well as in many countries around the world, lead to an increase in the proportion of older people in the general population. Seniors form a diverse social group in terms of cultural characteristics, social status, health problems, and economic and social situation. They are ageing at different paces, hence their needs, forms of activity and lifestyles are different (Bromley 1969). Today, old age is perceived as a culturally constructed stage of life, and ageing as a natural life process (Hamilton 2016). Such a change took place thanks to the social activity of the elderly as well as a range of actions targeted at seniors, promoting successful, active old age combined with a wide educational offer for seniors. Demographic forecasts also show that the ageing of populations will be faster in southern and eastern European countries, i.e. in relatively poorer regions of Europe. This may result in significant socioeconomic disparities between countries and lead to social discontent and conflicts. The whole world is ageing, but this process is fastest in Europe, where the phenomenon commonly referred to as the daddy boom coincides with population decline. Considerations on the causes and consequences of human ageing 
have led to the development of many theories attempting to explain the core of this process, for example the activity theory of ageing by R.J. Havighurst, Erikson's theory of psychosocial development, or the model of successful ageing by P.B. Balets.

All these concepts are consistent as to the fact that old age is a constructed image of human existence, combining health status with personality traits and life activity. According to the World Health Organization (WHO), the ages 45-59 are classified as middle-aged, 60-74 as old, 75-89 as elderly, and 90 and over as senility. An important element of international social policy targeted at seniors is a focus on activities in the area of education and programmes of preventive gerontology. Active seniors, as concluded by the World Health Organization, have less significant health deficits and greater psychophysical fitness, thereby reducing the cost of healthcare. The active population of elderly people in different dimensions are people who have a greater ability and willingness to work as well as to use educational offers, thus making a significant contribution to the development of society (Osiński 2003). A study carried out by the MacArthur Foundation revealed that "about 70 percent of the aging process can be controlledmodified, improved, namely changed for better. Old age can be bealthy and satisfying for seniors".

The aim of this article is to explain the idea behind universities of the third age as an unquestioned need to support seniors in education and adaptation to old age.

\section{Area under study}

Regardless of scientific discipline and cultural determinants, human activity has been widely analysed in studies on old age and ageing. Activity is usually defined as a natural tendency to act, a way of communicating with other people and the environment. Theories of adaptation to old age assume that at this stage of life seniors are able to maintain or even increase their previous activity in family, social and sometimes professional life, as well as to improve the quality of life related to its meaningfulness (Steuden 2010). One of popular theories proclaiming the need for education is the activity theory, which assumes that people who lead active lifestyles, especially professional, are more satisfied with their quality of life.

The activity theory assumes that seniors who were productive and committed for many years of their life successfully adapt to ageing. Through social activity, the elderly are more confident and have positive self-assessment. The gaps that were created after ending careers are usually filled with other activities or roles, e.g. involvement in charity work or participation in a range of educational programmes, e.g. universities of the third age. One example of good practice in the use of the social capital of seniors is their membership in Universities of the Third Age (U3A), which are centres for the education of the elderly. The first U3A in Europe was established in 1973 by Pierre Vellas, professor of international law at the University of Toulouse. Universities of the Third Age are the most popular forms of education for older people in Poland and in other countries worldwide. This initiative meets a growing interest from seniors who find it important to satisfy their needs, such as self-learning, acquisition of new knowledge and skills, the need to be recognized, and maintain interpersonal relationships, or the opportunity to follow their hobbies and dreams for which they had no time before (Jachimowicz 2012). The primary goal of U3A is to "improve the quality of life of the elderly, 
create conditions for successful ageing, overcome erroneous stereotypes and misconceptions attributing to the elderly the roles of physically and mentally handicapped people. This goal is achieved by including the elderly in the system of lifelong learning based on the intellectual, scientific and material potential of universities" (Newsletter of the U3A Section of PSG, 1986). There are two main models of U3A (and their variants), which differ primarily in their links to academic centres:

- French model - U3As are closely linked to academic centres. They are characterized by a high level of didactic and scientific and research activity, diversified in terms of organizational forms (full integration with the university, close cooperation or autonomy from universities),

- $\quad$ British model - based on self-learning and self-help of seniors, without support from universities.

The first Polish U3A was established in 1975 at the Postgraduate Education Centre in Warsaw by Prof. Halina Szwarc. U3As that were established in Poland operate based on the French model. This means that U3As closely cooperate with traditional universities, carry out didactic, scientific and research activities, and mainly involve speakers who are academic teachers.

Universities of the third age, apart from the basic form of activity, which is lectures on various subjects, also organize occasional meetings, tourist trips, workshops on the use of modern technologies, language courses, as well as recreational and sports activities (Rynkowska, Błaszczuk 2016). Topics of classes are chosen to match the interests of the members, and each year are established by the U3A Programme Council, alone or in consultation with U3A members. In 2018 there were 640 universities of the third age in Poland, operating mainly for the education, integration and activation of older people in order to improve the quality of their life and increase their participation in social life.

U3As exist in all Polish provinces, with the highest number (80) in the Mazowieckie province. The increase in the number of U3As is driven by several factors, including the increase in the number of retirees in Poland, the systemic support granted to U3As, or the emergence of a new generation of retirees who, due to the fact that most of their career coincided with the capitalist era, have different requirements, needs, lifestyles, and choices as to spending free time. It is worth noting that U3As grow most dynamically in cities, mainly in Warsaw and towns with populations up to 50,000. The largest number of U3As exist in the Mazowieckie, Śląskie, Dolnoślaskie and Wielkopolskie provinces. However, only $11 \%{ }^{[3]}$ of all U3As operate in rural areas. According to statistics presented in the report "Zoom on the Universities of the Third Age", access to U3As is lowest in three provinces: Świętokrzyskie, Podlaskie and Podkarpackie. 


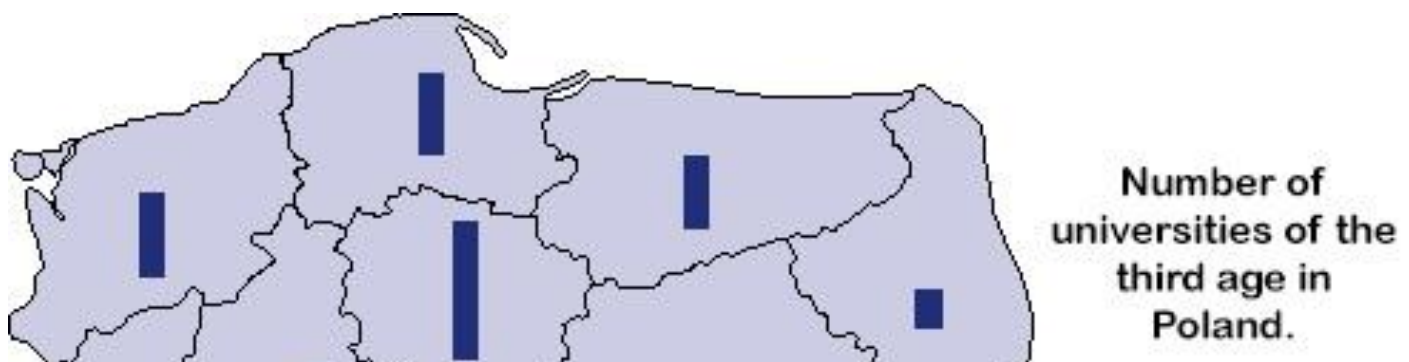

Fig. 1. U3As in Poland www.stat.gov.pl

Most Universities of the Third Age operate under four organizational forms: as autonomous non-governmental organizations (usually associations), organizational units operating within public or private universities, as separate entities within a nongovernmental organization, or as entities operating in the structures of local administration units (community centres, social welfare centres).

\section{Methodology}

The objective of the present paper was to analyse the forms and scope of services provided by the University of the Third Age in Kraśnik. The U3A in Kraśnik was established on 6 November 2002 as part of the active support of local authorities and the U3A Branch in Lublin. Currently, the U3A in Kraśnik has 170 active members (135 women and 35 men). The core of the analyzed problem was to identify the demand for educational services and the offer of the U3A in Kraśnik in this respect based on a survey conducted in October 2019. One of the basic goals of U3As is to create opportunities for the elderly who would like to continue their education. One of the reasons that made U3As popular is the fact that they fit into the ideas of open education. Their main goal is to educate the elderly. It is a format of educational activity that helps seniors to satisfy their needs for self-learning, exploring the environment, acquisition of knowledge and skills, involvement in activities for the benefit of the 
society, spending free time, maintaining social relationships, mental and physical stimulation, and sometimes even the possibility to fulfil the dreams they pursued at a younger age.

\section{Results}

The questionnaire was addressed to the whole population of U3A members, i.e. 170 people (whole sample). Completed questionnaires with a satisfactory level of answers (without missing data or with a negligible number of data) were returned by 161 respondents. This means that the response rate was at the level of $95 \%$ of the population, which makes the survey highly representative. The maximum error for the study sample was only $2 \%$ at a confidence level of $97 \%(\alpha=0.97)$.

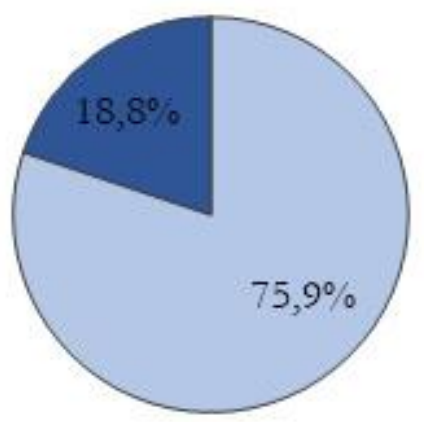

women

men

Figure 2. Members of $U 3 A$ by sex $(N=161)$

author's own analysis

U3A members are people of retirement age, or receive disability pension, are approaching retirement age, and declare voluntary participation in classes, want to broaden their knowledge, develop their interests, as well as take an active part in cultural life regardless of their level of education. It should be emphasized, however, that those who want to use the services offered by most Universities of the Third Age have to meet certain requirements, for example, have the status of a retiree, and be of a certain age. Most members of the U3A are aged $61-75$ years $(71.9 \%)$. 


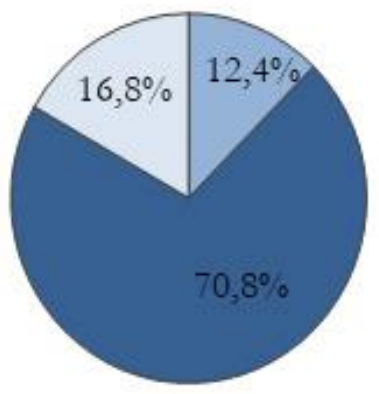

under 60 years

61-75 years

76 years and older

Figure 3. Members of $U 3 A$ by age $(N=161)$

author's own analysis

Lifelong learning at the $\mathrm{U} 3 \mathrm{~A}$ is offered in a variety of forms, including workshops, seminars, computer courses, language courses and sports activities. The U3A in Kraśnik offers various types of activity, primarily lectures, seminars, regular classes, including workshops, courses, interest circles, as well as cultural and artistic activities, and often charity work for people in need from the local community. Among the activities proposed by the $\mathrm{U} 3 \mathrm{~A}$, the most popular are regular lectures and seminars, mainly in the field of medicine and gerontology $(81 \%)$, followed by sports activities such as swimming, gymnastics and dance (58\%), computer courses (54\%), and language courses (49\%). The U3A also organizes cultural and artistic events. The most popular among them are excursions and tours, as well as outings to the cinema, theatre, museum or other cultural institutions. The U3A in Kraśnik has also organized charity actions for people in need not affiliated in the U3A. Aid from U3A members was targeted mainly at the elderly, the local community, children and adolescents. In 2019, the average attendance of members in regular classes was over $73 \%$.

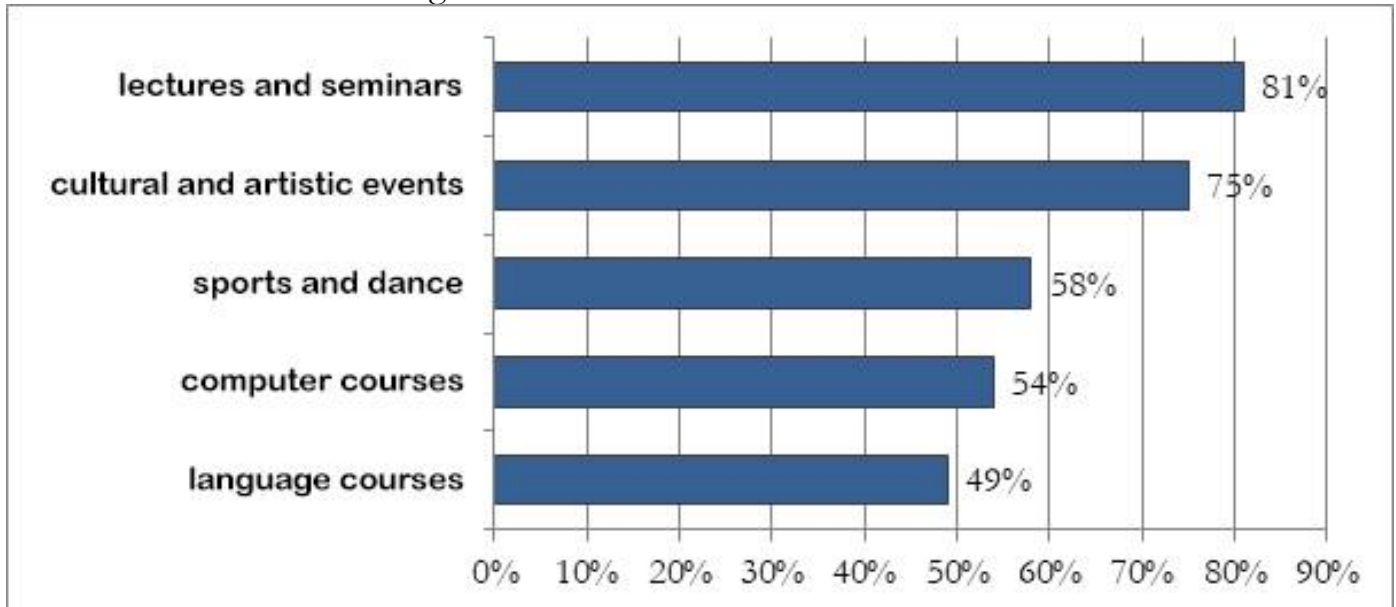

Figure 4. Interest in the programme offered by the U3A in Krasnik, author's own analysis 
Participation in classes of the University of the Third Age, acceptance of responsibilities arising from membership, the need to choose specific types of activities, and planning time at hand makes people feel more needed and makes them feel their life is more meaningful. Interest in newly learned problems and acquired information makes elderly people mobilized both mentally and physically, and increases their level of activity.

In the survey seniors were asked about their reasons for joining the U3A. The study revealed that most respondents decided to join the U3A because they wanted to acquire knowledge and new skills (over 80\%). The decisive reason was the constant need to explore the world and the self. Fifty percent of the respondents declared that they wanted to meet new people as the main motive for membership of the U3A. A smaller proportion of respondents decided to join the U3A because they had too much free time.

The analysis of empirical material showed that the vast majority of U3A members (almost 90\%) were learning from books and the press. Over $73 \%$ of the respondents declared that they acquired knowledge from mass media. About $75 \%$ of the U3A members attended lectures. Over half of the respondents used valorisation methods when participating in cultural life. A similar number of respondents used active observation for learning. Most U3A members learned from textbooks $(85 \%$ of the respondents declared reading them very often or often). Almost the same number of respondents declared using audiovisual equipment (television, radio). About $40 \%$ of the respondents acquired information from the internet.

Gathered data indicated that the need to follow interests and generally defined educational needs are the most important factors for seniors affiliated at the U3A in Kraśnik.

\section{Discussion and conclusions}

According to H.P. Tews, one of the precursors of the sociology of old age, the objective of social policy with respect to old age is to draw conclusions from the ongoing demographic changes and predict their consequences. This view can also be extrapolated to other aspects of the public projects targeted at the elderly, and it can be concluded that the entire policy on the ageing of societies and old people must consider and anticipate the short-term and long-term consequences of demographic transformations (Błędowski 2002). Measures for the support of the ageing society include not only broadening or introducing new benefits of material nature, but also offering educational activities to prepare the society for the increase in the proportion of old people. The increase in the number of old people in the community is accompanied by changes in their behaviour and attitudes, which brings a kind of new quality to interpersonal relationships, level of education, and the activity and independence of the older generation. This independence is reflected, for example, in developing personal interests, more open demonstration of old age understood not as the terminal period of human life, but in part as a time free from work-related duties that can be spent to pursue one's own plans.

Senior members of the community have benefited least from economic transformations, progress in technology and increase in the wealth of societies that have taken place in the 
world and in Poland in recent years (Auleytner, Głabicka 2000). Many of these people had to stop their education at a certain point of life for economic reasons or because of personal circumstances. As a result, they still have needs to satisfy with respect to selflearning, exploration of their environment, acquisition of new knowledge and skills, involvement in activities for the benefit of the community, recognition as members of society or a certain group, making use of free time, to maintain social bonds, mental and physical stimulation, as well as the possibility to realize their dreams that were previously impossible to pursue because of career and family duties (Skibińska 2008). In this context, the need to create a platform enabling retired people to have an active and satisfying life gains particular importance. One of many possible ways to achieve this is to popularize and support the operation of Universities of the Third Age, which can become organizations of natural activity for seniors just like the workplace, university, school, etc. are for younger people. Certainly, one of the most important challenges for the state and other institutions is to create and provide seniors with adequate community, social and educational services in response to the social needs identified in this group, especially those of an activating and educational nature. For many years, the need to improve not only medical and geriatric care, but above all to present the offer of activating and educational services has been emphasized when debating the problems of the ageing society. The years-long experience of gerontologists shows that the education of seniors is important for the prevention of many health problems common in this age group. When emphasizing the unquestioned need to support the educational development of people, including the elderly, the ideas of universities of the third age should be popularized around the world. U3As are becoming particularly important in view of the ageing of Polish society. Demographic transformations force lifting the thresholds of old age, thus the productive period is getting longer, and in turn people retire at an older age. An important issue for Poland and other European countries is to look for systemic solutions that would position the elderly at the right place in the society and create conditions for a dignified life in a safe and friendly environment (Szarota 2008). It should be kept in mind that due to the rapid ageing of European societies, seniors will increasingly require care and attention, not only from their family members, but also from many different institutions. According to the organizers, the idea of a university of all ages promotes broadly defined sharing between generations. Universities of the Third Age respond to the needs of the growing group of people of retirement age and have many useful functions, for example, they activate older people, help to maintain social ties, broaden the knowledge and skills of these people, and facilitate contacts with various institutions, such as healthcare, rehabilitation centres, and cultural centres. U3As are important educational and cultural centres for seniors. Older people affiliated at U3As have a chance to acquire new skills and competencies, but can also actively participate in the life of local communities. The operation of U3As is targeted at the active involvement of the elderly in the multidimensional process of education and social integration.

Universities of the Third Age are one of the most popular and diversified ways for the inclusion of older people in the process of lifelong learning. They help seniors update and broaden knowledge, increase their intellectual and physical activity, and prevent the social exclusion of older people. 


\section{References}

Auleytner J., Głębicka K. (2000). Polityka społeczna pomiędzy opiekuńczością a pomocniczością.

Balets P.B. (1987). Theroretical Propositions of Lifespan Developemental Psychology: On the Dynamics between Growth and Decline. Developemental Psychology No 23, s.15-29.

Bromley D.B.(1969).Psychologia starzenia się.

Erikson E.H. (1998).The Life Cycle Completed

Hamilton I.S.(2016). Psychologia starzenia się.

Havighurst R.J.,Albrecht R. (1953).Older people.

Jachimowicz D., Nalepa W.(2012). Tworzenie Uniwersytetu Trzeciego Wieku- Krok po kroku, Wydawnictwo Ogólnopolska Federacja Stowarzyszeń Uniwersytetów Trzeciego Wieku, s.7.

„Na temat" (2005) No 2,s.1.

Osiński W.(2003).Antromotoryka,s.12.

Raport z badania „Zoom na UTW"(2012).http://zoomnautw.pl/wpcontent/uploads/2012/05/Zoom_na_ UTW_RAPORT_calosciowy_www.pdf, (15.04.2020).

Rynkowska D., Błaszczuk K. (2016). Problemy społeczne i opiekuńcze seniorów i ich rodzin. Studium socjologiczne na przykładzie opinii pracowników socjalnych.

Skibińska S.(2008).Proces kształcenia seniorów, [w:] A. Fabiś (red.), Aktywność społeczna, kulturalna i oświatowa seniorów.

Steuden S.(2012).Psychologia starzenia się i starości.

Synak B. (2002). Polska starość.

Szatur-Jaworska B.(2000). Ludzie starzy i starość w polityce społecznej.

Szarota Z.(2008). Przestrzeń edukacyjna Uniwersytetu Trzeciego Wieku.No3(25). 